\title{
SHOPLIFTING AND THE LAW OF ARREST: THE MERCHANT'S DILEMMA
}

Shoplifting is the theft of goods displayed for sale. ${ }^{1}$ Today, with retailers" emphasis on uncovered display and "self-service,"2 the annual number of such thefts runs well into the millions. ${ }^{3}$ American store thieves, from the occasionally tempted amateur to the studied professional, ${ }^{4}$ steal annually merchandise with a retail value of over $\$ 250$ million.5 And shoplifting is apparently an uninsurable risk. ${ }^{6}$ Behind this common form of theft is often a ganglion which sends shoots into other areas of criminal enterprise. ${ }^{7}$ Yet the incessant and systematic sack of retail stores is accomplished with little risk of arrest and prosecution. ${ }^{8}$ Merchants and police must combat the shoplifter with unwieldly and outmoded laws delimiting the right to apprehend him and bring him before legal authority. ${ }^{9}$ Currently, the awakened interest of merchants reinforces the

1. This is the description employed in the records of most metropolitan police departments. Interview with Raymond J. Eagan, Capt. of Detectives, New Haven, Conn., Dep't of Police Service, November 18, 1952.

2. Address of Edward Wetton, Div. Operating Mgr., Stix, Baer \& Fuller Dept. Store (St. Louis, Mo.), at Store Management Sess., Convention of Nat. Retail Dry Goods Ass'n, January 14, 1953 (copy in Yale Law Library). See also Pollak, The CrnuinalITY OF WOMEN 34-5 (1950).

3. See Sterling, Stop That Shoplifterl, The Saturday Evening Post, October 22, 1949, pp. 19, 67.

4. See text at notes 18-29 infra. The Operating Director of the Chicago Crime Commission has concluded that shoplifters ". . . are among the most professionalized of our lawbreaking population." Peterson, Crime Does Pay, The Atlantic, February, 1953, p. 41.

5. It is estimated that variety stores charge off $1 \frac{1}{2}$ percent of total dollar sales to pilferage loss, while department and drug stores recognize a 1 percent loss and grocery stores, 1/4th of 1 percent. Cracking Dozen on Shoplifters, Business Week, November 1 , 1952, p. 58. This means, on the basis of 1948 United States Census of Business retall sales figures, that the American shoplifter in that year occasioned losses approximating: $\$ 146,580,000$ in drug and department stores, $\$ 51,925,000$ in grocery stores, and $\$ 37,601,000$ in variety stores: a total of $\$ 246,106,000$. Inflation and an uptrend in the crime have undoubtedly swelled the "take" since 1948.

6. "[S]hoplifting losses are not considered insurable. . . This is largely because it would be next to impossible to determine just what part of stock shortages . . . could bo charged to this type of theft." Communication to the YALE LAw JourNal from a leading insurance company, dated October 31, 1952. (Name of company withheld by request.)

"The high frequency of the losses and the small amount involved in each incident would cause the expense of investigating and making reimbursement to exceed the pronportion considered appropriate. ..." Communication to the YALE LAw JouRNAl from a leading insurance company, dated December 18, 1952. (Name of company withheld by request.) See also Crobaugh \& Reding, Casualty Insurance 607 (1928).

7. See text at notes 30-8 infra.

8. See APPENDIX, infra.

9. See pages $792-7$ infra. 
desire of law enforcement agencies to reach the shoplifter and the men behind him. ${ }^{10}$ Without jeopardizing the shopper's freedom from arbitrary restraint, the law of arrest must be remolded to form a sharper weapon against shoplifting.

\section{The Nature of the Crime}

A form of larceny, ${ }^{11}$ store theft denotes the non-consensual taking and carrying away of a merchant's property, with an intent permanently to deprive him of possession. ${ }^{12}$ The store thief must grasp the article ("caption") 13 and, in the absence of a statute to the contrary, move the article from its resting place ("asportation"). 14 Even momentary possession combined with any removal fulfills the requirement of caption and asportation. ${ }^{15}$ The essential element of intent to steal, however, usually must be inferred from proof that the accused made an elaborate attempt to conceal the item on his person ${ }^{10}$ or that he carried it out of the store without offering payment. ${ }^{17}$

10. See note 118 infra and accompanying text.

11. See, generally, Miller, Crairnal L.w $\$ \$ 109-115$ (1934); Rapalje, Ladce:iY $\$ \$ 1-305$ (1S92).

12. Cf. Black v. State, $\$ 3$ Ala. $\$ 1,3$ So. $\$ 14$ (1S8S); People v. Hoban, 240 III. 303 , ES N.E. $S 06$ (1909): Dunlavey v. Commonwealth, 184 Va. 521, 35 S.E.2d 763 (1945). See also, An Attorney at Law, The Law of Arrests in Botn Crm nas Crusimal CAses 148 (1742).

13. Cf. People v. Williams. 73 Cal. App.2d 154, 166 P.2d 63 (1945); People v. Batier, 365 I11. 32S, 6 N.E.2d 665 (1936); Rosenbush v. State, 136 Tex. Crim. 50. 122 S.W.2d 1071 (1938).

14. Cf. People v. Edwards, 72 Cal. App. 102, 236 Pac. 944 (1925); People v. Wall:er, 361 Ill. 482 , 198 N.E. 353 (1935). For a statute abolishing the asportation requirement, see Tex. Penal Code art. 1412 (Vernon, 1925), Krause v. State, 151 Tes. Crim. 197, 206 S.W.2d 257 (1947).

15. E.g., Blakeney v. State, 244 Ala. 262, 13 So.2d 430 (1943); People v. Dulke, 16 Cal. App.2d 105, 60 P.2d 197 (1936) : Fitch v. State, 135 Fla. 361, 185 So. 435 (193\$).

16. E.g., People v. Lardner, 300 Ill. 264, 133 N.E. 375 (1921) ; People v. Bradovich, 305 Mich. 329, 9 N.W.2d 560 (1943). See Address of Ralph Garber, Chief Ass't Prosecuting Att'y of Wayne County, Mifich., before Store Míanagement Sess., Store Mranagement and Personnel Groups Convention of Nat. Retail Dry Goods Ass'n, May 2f, 1950.

17. See Hutzer, The Policewongan's Handroos 23 (1933); O'Surlwayi, Crnote Detection 36 (1928). See also W. T. Grant Co., The Grasit Stone Mazual 3 (June 25, 1951) ; Retanl Merchants Ass'n of Houston, Ixc., Shorlafturg (pamphlet, nd.) (copy in Yale Law Library); Communications to the Yale Law Jounsul from Harry J. Daniels, Chief of Detectives, New Orleans, La., Dep't of Police, dated November $\mathbf{2 5}$, 1952; and Harold Anderson, Chief of Detectives, Kansas City, MFo., Police Dep't, dated December 16, 1952; in the Yale Law Library.

Writers of insurance against liability for false imprisonment attach the condition that shoplifting arrests be made of the insured's premises. See Communication to the Yare Law Joundal from P. Tarbetsky, Ass't Superintendent, Nat. of Hartiord Group, disted December 9, 1952, in the Yale Law Library. This illustrates a feeling that proof of intent will be dificult if an arrest is made before the suspect has leit the premises. 
Among the diversified dramatis personae of the crime, the pilferers for profit present the most enticing target for police efforts. True, about 70 percent of shoplifters are amateurs, ${ }^{18}$ usually women ${ }^{10}$ and juveniles, ${ }^{20}$ who steal for personal use. (Kleptomaniacs, who steal to satisfy a neurotic compulsion,21 seem comparatively rare. ${ }^{22}$ ) But a shopper in this otherwise law-abiding group will steal only on rare occasions, ${ }^{23}$ usually when tempted by alluring advertising and an unguarded display. ${ }^{24}$ Though a smaller group, professional store thieves probably occasion greater dollar losses to retailers, ${ }^{25}$ since their forays, unlike those of the amateur, are frequent and selective, ${ }^{20}$ and the expert shoplifter is more likely to go undetected. ${ }^{27}$ Amateurs, apprehended and reprimanded by the merchants themselves, rarely repeat the offense; $; 28$ but only

18. See Cracking Dozen on Shoplifters, supra note 5, at 58. See also Anderson, Further Studies of Delinquent Personalities in Proceedings of the AMericun Prison AssoCIATION 439-44 (1919).

19. See Ettinger, The Problem of Crine 27 (1932);. Gross, Adnu \& AduM, Criminal Investigation 509 (3d ed. 1934).

20. See Weir, Criminozogy 28-9 (1941); Cracking Down on Shoplifters, supra note 5, at 58; Retail Mercenants Ass's of Houston, Inc., op. cit. supra note 17; ShopliftING IN Detroit 1 (mimeo. release by Detective Lt. George McArthey, Dep't of Police, Detroit, Mich., n.d.) (copy in Yale Law Library).

21. See Davidson, Forensic Psychiatry 319, 326 (1952). For a theory of sexually motivated kleptomania, see Abra hamsen, Who Are the Gullty? 150-2 (1952). Sce also Henderson, Psychopathic Constitution and Criminal Behavior in Mental Adnonandity AND CRIME 118 (1944). For a purported kleptomaniac's diary, detailing her mental processes, see Anon., A Kleptomaniac's Mind, The Atlantic Monthly, July, 1937, p. 43.

22. Merchants believe that fewer than 1 percent of pilferers are kleptomaniacs. Sec Anon., When Lovely Woman Stoops to Stealing, Collier's, August 22, 1925, p. 11; Sterling, supra note 3, at 67; Retail Merchants Ass'N of Houston, Inc., op. cil. sutpra note 17.

23. See statement of W. J. Wallace, Sec'y-Mgr., Retail Merchants Ass'n (Houston, Texas), in Store Mgrs. News Bull. of Nat. Retail Dry Goods Ass'n, 3d Quarter, 1052, p. 11 (copy in Yale Law Library). See also ANDERson, op. cit. supra note 18, at 439-44 (1919); and Grassberger, Geiverbs-UNd Berufsverbrechertum in DEN VereinigteN StaAten von AMrerika 297 (1933).

24. See Grout, Burglary Risks 135 (1927) ; Potlak, op. cit. sipra note 2, at 34-5. For other possible motivations underlying amateur shoplifting, see Cracking Dozm an Slooplifters, supra note 5, at 61.

25. See Sterling, supra note 3 , at 69.

26. See Sutherland, Principles of Criminology 213-14 (4th ed. 1947). Professional shoplifters develop a high degree of skill in their craft, ETTINGER, op. cil. supra note 19, at 26, and are often organized, SUTHERLAND, op. cit. supra, at 208. Specialized techniques of professional pilferers are described in SöDERMAN \& O'CONNELL, MODERN Criminal Investigation 372 (4th ed. 1952). For a case history of organized shoplifting over a wide geographic area, see Hoover \& Collins, Slickers in Slacks, Collier's, October 16,1943, p. 24.

27. See, e.g., Hutzel, op. cit. supra note 17, at 27 ; Pollak, op. cit. supra note 2, at $35-6$.

28. See MacDonald, Crime Is a Business 220 (1939). "[I]n many cases, merely the embarrassment of being caught 'red-handed' is sufficient to return the [amateur] of- 
prosecution and incarceration of professional "boosters," effecting complete removal from circulation, appear to curtail their activities. 00

Arrest of the professional shoplifter may serve goals other than the protection of store owners' property. Under police questioning, the veteran store thief may supply vital information illuminating other areas of organized crime. The professional pilferer invariably is connected with one or more receivers of stolen goods ${ }^{30}$ who, for resale. purchase the plunder of thieves at about one-fourth its value.31 These "fences," frequently part of an inter-city network, ${ }^{32}$ provide the profit motive underlying not only store larceny, but also many other forms of professional theft. ${ }^{33}$ Often the receivers lay the plans for theft campaigns ${ }^{34}$ and may frustrate arrest and prosecution by wholesale bribery. ${ }^{35}$ Thus, incarceration of one receiver following an apprehended shoplifter's "tip" may thwart the activities of large numbers of professional thieves by destroying their source of instruction and protection, and their sales outlet. Arrest of professional pilferers may also result in the disruption of local traffic in narcotics. The incidence of drug addiction among store thieves appears to be extremely high: police authorities and retail associations have estimated that from 30 to 90 percent of professional shoplifters, depending on the locality; are addicts. ${ }^{36}$ Of necessity, addicts maintain periodic contact with narcotics peddlers. In fact, peddlers, aware that the nation's addicts must support a

fender to the straight and narrow path." Address of Ralph Garber, supra note 16. See also Communication to the YALE LAw Journal from Robert N. Bolitho, Public Relations Dir., Retail Merchants Ass'n of Houston (Texas), Inc., dated November 2, 1952, in the Yale Law Library.

29. See Retail Mierchants Ass's of Houston, INc, op. cit. supgra note 17.

30. See Ass's of Grand Jurors of N.Y. Countr, Crousind Recenvers in tae UnITED STATES (1928) passim.

31. See id. at 12, 13; Jandy \& Floch, Narcotic Apdrctron as a Factor iz Pettr LafCeny in Detrort 13 (1937); Klingman, The Booster, the Heel, and the Snitch, Parl: East, January, 1953, p. 14.

32. See Sutherland, Princtples of Criminology 208 (4th ed. 1947).

33. See Ass'n of Grand Junors of N.Y. County, op. cit. supra note 30, fassim.

34. See Sutherland, Principles of Causmulogy 208 (4th ed. 1947). The role of "fences" is not new. See Colguhoun, A Treatise on tae Police of zHe Mimorous 176 (4th ed. 1797).

35. See Ass'N of Grand Junoss of N.Y. Country, op. cit. supra note 30, at 15; Sönendran \& O'Connel, op. cit. supra note 26, at 357; Sutherlasid, Paniciples of Criminology 165-6 (1st ed. 1934).

36. See Retall Merchants Ass'n of Houston, Inc, op. cif. sipra note 17; Communication to the Yale LAw Jourast from J. D. Holstrom, Berkeley, Calif, Chief of Police Dep't, dated December 3, 1952, in the Yale Law Library. See also IAsid: \& FLocr, op. cit. suppra note 31, passinz; Sutherland, The Peoressionzar Thier 40 n.5 (1937); Hearings before Committee on Ways and Means on H.R. 3490 and H.R. 348, S2d Cong., 1st Sess. 41 (1951). A Los Angeles, Calif., police official has stated that 20-25 percent of jureniles apprehended for shoplifting are "tied up" with narcotics. Crachisg Doars or: Shoplifters, supra note 5, at 61. See Comment, 62 YALE L.J. 751 (1953) fassim. 
habit costing from $\$ 30$ to $\$ 120$ a week, ${ }^{37}$ frequently suggest store larceny to their customers as a means of raising money for drugs. ${ }^{38}$ Thus, arrest of an addict-shoplifter carries the added incentive of suppressing illicit trade in narcotics. Furthermore, law enforcement agencies are interested in the apprehension of juvenile store thieves, for shoplifting often constitutes youth's initial experiment in crime. ${ }^{39}$ If apprehended early and entrusted to juvenile guidance personnel, young persons may be diverted from further and more ambitious criminal activity. ${ }^{40}$

Despite recognition by both police and merchants of the gravity of the crime and the importance of effective apprehension, only a small fraction of the shoplifting offenses known to American retailers are reported by them to the police. ${ }^{41}$ In 1951, for example, the Department of Police of Detroit, Michigan, recorded 428 reported cases of shoplifting for the entire city, ${ }^{42}$ while during the same period the protection service of a single large Detroit department store detected over twice that number. ${ }^{43}$ And in the same year, the Department of Police of Worcester, Massachusetts, a city of 273,949 poputation, recorded only two known cases of shoplifting. ${ }^{44}$ Due in part to this paucity of reports to police, the number of arrests and prosecutions for store larceny throughout the nation is small. ${ }^{45}$ A prime reason for the reluctance of American merchants to seek the arrest and prosecution of pilferers may be found in the restrictive legal rules circumscribing lawful apprehension of shoplifters.

\section{The LAw of Arrest}

In a criminal case, an arrest is the taking of a person into custody for the purpose of bringing him before a court or appropriate official to answer an allegation of criminal activity. ${ }^{40}$ And private citizens as well as peace officers

37. See Hearings, supra note 36 , at 41 . These figures are conservative estimates. Sec Stevens, Make Dope Legal, Harper's Magazine, November, 1952, p. 41.

38. See Hearings, supra note 36 , at 63 ; Sterling, stipra note 3 , at 72 .

39. See Burt, The Young Delinguent 449 (4th ed. 1944); Russell \& Rigur, The Making of the Cruarinal 80-1 (1906); Weir, op. cit. supra note 20, at 28-9.

40. See note 28 supra. "It is the ease with which [amateurs] are able to pursuc this racket that causes them to continue. ..." MacDonaLd, op. cit. supra note 28 , at 220 . Sce also BURT, op. cit. supra note 39 , at $452-3$.

41. See ApPENDIx, infra.

42. Ibid.

43. Communication to the Yale Law Journal, dated December 1, 1952. (Name of store withheld by request.)

44. See APPENDIX, infra.

45. Ibid.

46. E.g., Davis \& Allcott Co. v. Boozer, 215 Ala. 116, 110 So. 28 (1926); Rhodes v. Walsh, 55 Minn. 542, 57 N.W. 212 (1893); State v. District Court, 70 Mont. 378, 225 Pac. 1000 (1924). See also Restatenent, Torts \$112 (1934); Perkins, The Luze of Arrest, 25 Iowa L. REv. 201 (1940). 
may make arrests. ${ }^{47}$ An arrest may be effected by words joined with physical touching or seizure, ${ }^{48}$ or by oral statements alone if the arrestee is thereby put in fear of force and submits. ${ }^{29}$ But not every detention is an "arrest" in the technical sense of the word." The merchant who halts a suspected shoplifter with no intention of turning him over to the police or prosecuting him in court may be "imprisoning" the suspect, but he is not "arresting" him.

The arrest rules usually applicable in store pilferage cases are those governing arrest for misdemeanors without warrant. The shoplifter ordinarily captures only relatively inexpensive merchandise: amateurs are afraid to steal costly articles or in quantity, and most professional pilferers are careiul to avoid the harsh penalties attaching to felony-thefts. 12 Moreover, merchants usually have the good sense not to display expensive articles within easy reach of the sticky-fingered shopper. ${ }^{53}$ The Chief of Protection for one of the nation': largest department stores has estimated that the average "grab" involves item: worth about $\$ 15 .^{54}$ Consequently, shoplifting is normally a misdemeanor in states differentiating between grand and petit larceny on the basis of valueof-goods-stolen. ${ }^{\mathrm{sJ}}$ And arrest of store thieves must be made without process,

47. Private Persons: E.g., Ald Code tit. 15, $\$ 158$ (1940), E. I. Du Püt de Nemours Powder Co. v. Hyde, 201 Ala. 207, 77 So. 733 (1917); CAL. Pesul Cope \$ $\$ 37$ (Deering, 1941), Hill v. Nelson, 71 Cal. App.2d 52S, 162 P.2d 927 (1945).

Peace Officers: E.g., FLA. Stat. Awn. c. 901, $\$ 901.15$ (Supp. 1952), Kersey v. State, 58 So.2d 155 (Fla. 1952) ; Ind. Stat. ANn. \$9-1024 (Burns, Cum. Repl. 1942), Harness v. Steele, 159 Ind. 286,64 N.E. $\$ 75$ (1902).

48. E.g., Thompson v. Boston Pub. Co., 285 11ass. 344, 189 N.E. 210 (1934) ; State v. MicClung, $123 \mathrm{~W}$. Va. 682,17 S.E.2d 621 (1940).

49. E.g., People v. Mirbelle, 276 Ill. App. 533 (1934); State v. Dunivan, 217 Mo. App. 548, 269 S.IV. 415 (1925).

50. See Wilgus, Arrest Without Warrant, 22 MIrce, L. Rev. 541, $541-57$ (1924).

51. Cf. McGlone v. Landreth, 200 Okla. 425, 195 P.2d 268 (1948). For cases of false imprisonment without arrest, see, e.g., Crews-Beggs Dry Gouds Co. v. Bayle, 97 Colo. 568, 51 P.2d 1026 (1935); Hassenauer v. F. W. Woolworth Co, 314 IIl. App. 569, 41 N.E.2d 979 (1942).

52. Interview, supra note 1. See also Sterling, sispra note 3 , at 67.

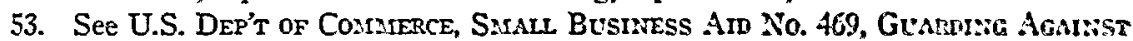
Theft of Retall Mrerchandise 2 (October, 1948); The Gentre Ant os Suorlirting and How to Resrove Tearptation (pamphlet, reprinted by the Nat. Cash Register Co. from The Centraz Prarmaceutical Jounnat, n.d.) (copy in Yale Law Library).

54. See Sterling, sapra note 3, at 67. For a suggestion that the average for 1953 may be somewhat higher, see Communication to the YALE LAw Jounsal from Michael F. Glynn, Gen. Mgr., Stores' Miutual Protective Ass'n, Inc (New York, N.Y.), dated March 3, 1953, in the Yale Law Library.

55. Interview, supra note 1. See also Communication to the YaLE Law Jurrial. from Michael F. Glynn, supra note 54.

The classification of store theft is controlled by statutes labeling the crims a fulung: (grand larceny) or a misdemeanor (petit lareeny), depending on the retail marliet value of the property stolen. The dividing-line varies in differert states frum $\$ 20$ to $\$ 500$. Ses, e.g., Mass. Axw. Laws c. 266. \$30 (Supp. 1952) (\$100); R. I. Ges. Luws c. 609 , \& 18 (1938) (\$500); W. VA. Cone Arvo. $\$ 5954$ (1949) (\$20). All larceny is made a felony in 
if at all, since in a shoplifting context there is almost never time to secure a warrant before the offender, unidentified, has departed with his plunder. ${ }^{60}$

Arrest without warrant for misdemeanors is hedged about by the strictest of rules. Under the usual common-law rule, neither a peace officer nor a private person may arrest without warrant for a misdemeanor even though committed in his presence. ${ }^{\mathbf{t 7}}$ And the subsequent securing of a warrant will not render lawful any restraint prior to its issuance. 88 The common law still governs peace officers ${ }^{59}$ in fourteen states ${ }^{60}$ and private persons in twentynine states ${ }^{61}$ and in the District of Columbia.

Many statutes modify, partially at least, the common-law rules. ${ }^{02}$ These statutes empower peace officers to arrest for misdemeanors without warrant in some situations. In thirty states and the District of Columbia the arrest is valid if the offense was committed in the arresting officer's presence. 00

four states. Ded. Code Rev. $\S 5200$ (1935) ; INd. Stat. ANn. $\$ \$ 10-3001,10-3002$ (Burns, Cum. Repl. 1942) ; Penna. Stat. Anv. tit. 18, $\$ 4807$ (Purdon, 1930) ; Tenn. Code Ann. $\S 10925$ (Williams, 1934). Shoplifting is made a felony by statute in one state. Micr. Stat. Ann. \$28.592 (Supp. 1951), People v. Huffman, 315 Mich. 134 (1946).

56. See Interview, supra note 1.

57. Peace Officers: E.g., Commonwealth v. Wright, 158 Mass. 149 (1893); Booth v. Hanley, 2 C. \& P. 288 (1826) ; Hardy v. Murphy, 1 Esp. 294 (1795).

Private Persons: E.g., Palmer v. Maine Cent. R.R., 92 Me. 399, 42 Atl. 800 (1899); Mathews v. Biddulph, 3 Man. \& G. 390 (1841); Fox v. Gaunt, 3 B. \& Ald. 798 (1832). See also 9 Halsbury, Laws of England $\$ 117$ (2d ed. 1933).

A few judicial decisions have extended the power of arrest. E.g., Callahan v. Statc, 163 Md. 298, 162 At1. 856 (1932) (peace officer may arrest without warrant for misdemeanor committed in presence); Muscoe v. Commonwealth, 86 Va. 443 (1890) (same). As to private persons in cases of theft, see Malley v. Lane, 97 Conn. 133, 115 Atl. 674 (1921) seinble.

In cases of misdemeanors amounting to breaches of the peace due to the presence of violence, a different rule applies. E.g., Quinn v. Heisel, 40 Mich. 576 (1879) ; Timothy v. Simpson, 1 Cr. M. \& R. 757 (1935). Shoplifting has never been deemed a breach of the peace. See Comment, 46 ILL. L. Rev. 887, 895 n.19 (1952).

58. Implicit in damage award in, e.g., Jefferson Dry Goods Co. v. Stoess, $304 \mathrm{Ky} .73$, 199 S.W.2d 994 (1947) (warrant not issued until suspected shoplifter taken to police station).

59. The term "peace officer" includes sheriffs and their deputies, constables, city and town marshalls, and policemen. See Wilgus, Arrest Without Warrant, 22 Micir. L. Rev. 541, 561-2 (1924).

60. Colo.; Conn.; Del.; Kans.; Ky.; Md.; Miss.; N.J.; N.C.; Texas; Vt.; Va.; Wash.; W. Va.

61. States listed note 60 supra, and: Ariz.; Ark.; Fla.; Ind.; La.; Me.; Mass.; Mich.; Mo.; N.H.; N.M.; Ohio; Penna.; R.I.; Wis.

62. In some cities, powers of arrest are extended by municipal ordinance. Sce, e.g., Munictpal Code of Chicago c. 173 (1939) (store employees); Szymanski v. Great Atlantic \& Pacific Tea Co., 79 Ohio. App. 407, 409, 74 N.E.2d 205, 206 (1947) (Toledo, Ohio; private policemen).

63. Ala. Code tit. 15, § 154 (1940) ; Ariz. Code Ans. § 44-124 (1939); Ark. Strut. Ann. $\$ 43-403$ (1947); Cal. Penal Code $\$ 849$ (Deering, 1941); Fla. Stat. Ann. 
Illinois and Iowa are more liberal, allowing a peace officer to arrest without warrant where a misdemeanor has been committed outside his presence if he has reasonable grounds to believe that the person to be arrested is guilty. ${ }^{\text {ct }}$ These two jurisdictions tolerate a reasonable error as to the offender. ${ }^{65}$ The arrest statutes of Rhode Island and Wisconsin go even further, allowing, in addition, a reasonable error as to whether an offense was in fact committed. ${ }^{\mathrm{ca}}$ Moreover, some statutes authorize private persons to arrest without warrant. Citizens of seventeen states possess this arrest power for misdemeanors committed in their presence. ${ }^{67}$ In Nebraska and Wyoming, citizens actually wield broader statutory arrest powers in cases of petit larceny than do peace officers, presumably because private persons are more likely to be at the scene. In these states a private citizen may arrest a petit larceny suspect if a theit has in fact been committed and reasonable grounds existed for believing the person arrested guilty of the offense. ${ }^{68}$

In sum, most statutes clothe either peace officers or private persons with power to arrest without warrant where three events coincide: (1) an offense has, in fact, been committed (2) in the presence of the person given authority

$\$ 901.15$ (1943); GA. Code ANw. $\$ 27-207$ (1938); Inamo Code $\$ 19-603$ (1948); I:*o. Stax. Ann. \$9-1024 (Burns, Cum. Repl. 1942); La Rer. Stat. tit. 15, $\$ 60$ (1950); Me Rev. Stat. c. 134, \$ 4 (1944) ; MLass. Ann. Laws c. 276, $\$ 28$ (Supp. 1951) (lareeny); Mirer. Stat. Ann. $\$ 2 S .874$ (1935) ; Minn. Stat. Ams. $\$ 629.34$ (1946); Mo. Rev. Stat. Ann. $\$ \S$, e.g., 6581,7674 (1943) ; M Iont. REv. Codes Anrs. $\$ 94-6003$ (1947); Nen REr. Stat. \$29-101 (1943) ; Nev. Coxsp. Laws $\$ 10751$ (Hillyer, 1929); N.H. Laws 1941, c. 163, §6; N.M. Stat. ANN. \$14-1606 (1941); N.Y. Crars. Cone \& Penal Law \$ 177 (Clevenger \& Gilbert, 1951) ; N.D. REv. CoDE \$29-0615 (1944) ; Oнro Gerr. Cone Azus. $\$ 13432-1$ (Page, 1939) ; OrLa. Stat. Ann. tit. 22, \$196 (1937); Ore Co:sp. Laws Amz. \$26-1532 (Bancroft-Whitney, 1940); Penna. Stat. Awn. tit. 53, \$1219S-2005 (Purdon, Supp. 1952) ; S.C. CODE of LAws $\$ \$ 17-251$ (larceny), 17-253, 17-254 (1952) ; S.D. Conz $\$ 34.1609$ (1939) ; TeNN. CODE ANN. \$11536 (Williams, 1934); UTAu Cune Ann. \$7713-3 (1953); Wyo. Cossp. Stat. \$10-301 (1946); D.C. Cone \$4-140 (1951).

64. Ill. AnN. Stat. c. 38, $\$ 657$ (Smith-Hurd, 1935), People v. Roberta, 352 Ill. 1\$9, 185 N.E. 253 (1933) ; Iowa Code Ann. \$755.4 (1950), State v. Small, 184 Iowa \&\$2, 169 N.W. 116 (1918).

65. Cf. People v. Caruso, 339 IIl. 258, 171 N.E. 128 (1930).

66. R.I. Pub. Laws 1941, c. 982, §68, cl. 5; Wrs. Star. §354.03 (1951), State v. Cox, 258 Wis. 162,45 N.W.2d 100 (1950).

67. Ala. Code tit 15, $\$ 15 \$$ (1940); Cal. Penal Code $\$ 837$ (Deering, 1941); Ga. Code ANN. §27-211 (1938); Idamo Code \$19-604 (1948); Ill. ANs. Stat. c. 38, §657 (Smith-Hurd, 1935); Iowa Cone Awr. \$755.5 (1950); Minns. Stat. Amr. \$629.37 (1946) ; MLNT. Rev. Codes ANN. $\$ 946004$ (1947); NEv. Cosp. Luws $\$ 10752$ (Hillyer, 1929) ; N.Y. Cran. Cone \& Penal Lav \$183 (Clevenger \& Gilbert, 1951); N.D. REv. Code $\$ 29-0620$ (1944); ORLA. Stat. Ans. tit. 22, \$202 (1938); Orfe Cossr. Laws Amz. \$26-1537 (Bancroft-Whitney, 1940) ; S.C. Cone of Laws \$17-251 (1952) (larceny) ; S.D. Code $\$ 34.160$ (1939); Tenn. Code Ann. $\$ 11541$ (Williams, 1934); UtaI Cone Ams. $\$ 77-13-4$ (1953).

6S. Neb. Rev. Stat. $\$ 29-402$ (1943), Morrow v. State, 140 Neb. 592, 300 ․W. 343 (1941); Wyo. Coגr. Stat. ANr. \$10-302 (1946). 
to arrest, and (3) the arrestee is, in fact, the person guilty of the offense. But modern-day merchants and police find even this statutory liberalization of arrest rules impotent against the shoplifting plague.

Store theft is a crime of stealth and rarely takes place in the "presence" of police or authoritative store personnel.60 Few police departments maintain even small shoplifting squads, ${ }^{70}$ and these men can lurk within view of only the barest fraction of pilferage offenses as they occur. Some prosperous mercantile establishments hire trained store detectives, ${ }^{71}$ but professional shop. lifting teams are quick to spot and decoy them from the area of intended theft. ${ }^{72}$ The same tactics may dispose of supervisory personnel. ${ }^{73}$ And an unlawful arrest results if a harassed supervisor or storekeeper who did not observe the theft attempts an arrest himself or summons a policeman from the street who did not see the "grab."74 The supervisor or storekeeper who instigates the arrest by calling the policeman, as well as the officer, is deemed an arrester. ${ }^{75}$

69. An offense occurs in a person's "presence" when his own senses render him aware that it is being committed. Hoppes v. State, 70 Okla. Crim. 179, 105 P.2d 433 (1940). Presence in a shoplifting case is defined as "within view." Cf. MACHEN, ThE LAw oF ARREST § 24(b) (1950).

70. Of 65 police departments responding to a questionnaire distributed by the YALE LAw JourNal, seven maintain a permanent anti-shoplifting squad: Kansas City, Mo. (4 men); Miami, Fla.; New Orleans, La. (2 men) ; Pittsburgh, Pa.; St. Paul, Minn. (2 men); San Antonio, Texas; San Francisco, Calif. Many others reported maintenance of such a squad during the pre-Christmas period, when shoplifting reaches its annual peak.

71. See Shalloo, Private Police 193-4 (1933). See also Nugent, Modern Store Protection in The "LAdY of Lyons" 27 (2d ed. 1943) (publication of Pinkerton's Nat. Detective Agency, Inc.) (copy in Yale Law Library). In some jurisdictions, store detectives possess police powers of arrest. See ShaLloo, op. cit. supra.

72. Interview with department store manager, New York, N.Y., November 15, 1952. (Name withheld by request.)

73. Ibid.

74. E.g., Hanna v. Raphael Weill \& Co., 90 Cal. App.2d 461, 203 P.2d 564 (1949); McDermott v. W. T. Grant Co., 313 Mass. 736, 49 N.E.2d 115 (1943); Montgomery Ward \& Co. v. Wickline, 188 Va. 485, 50 S.E.2d 387 (1948). Some cases appear to hold that a private person is not liable for false imprisonment where he, possessing the right to make a lawful arrest because the crime occurred in his presence, stummons a peace officer to make the arrest instead. E.g., James v. San Antonio A.P.R.R., 53 Tex. Civ. App. 603, 116 S.W. 642 (1909).

75. E.g., Aldridge v. Fox, 348 III. App. 96, 108 N.E.2d 139 (1952) ; McDermott v. W. T. Grant Co., 313 Mass. 736, 49 N.E.2d 115 (1943); Howell v. Viener, 179 Mliss. 872, 176 So. 731 (1937). The storekeeper would not be deemed an arrester where he merely laid the facts of the supposed theft before a peace officer who subsequently determined on his own initiative to arrest. E.g., Zinkfein v. W. T. Grant Co., 236 Mass. 228, 128 N.E. 24 (1920) ; Vimont v. S.S. Kresge Co., 291 S.W. 159 (Mo. App. 1927). Words such as "Stop that woman!" or "Take charge of him" constitute "instigation" of arrest. McGill v. Walnut Realty Co., 235 Mo. App. 874, 148 S.W.2d 131 (1941); Harris v. Terminal R.R. Ass'n of St. L., 203 Mo. App. 324, 218 S.W. 686 (1920). 
Salespersons are the most frequent witnesses to shoplifting. ${ }^{73}$ They are, however, often deterred by company directive from involing their statutory arrest power. ${ }^{77}$ Store managements, jealous of customer goodwill, fear that lesser employees may prove over-eager and undiplomatic, thus precipitating unnecessary scenes with suspected pilferers on the sales floor. ${ }^{78}$ But the most compelling reason for merchants' de-emphasis on arrest is rooted in the doctrine that all persons who arrest without warrant for misdemeanors do so at their peril :79 if the suspect later is found innocent the arrest vill be deemed unlawful, no matter how reasonable the arrester's suspicions. ${ }^{80}$ While training programs, work manuals, and bulletins can be employed to discourage store personnel from making reckless accusations, ${ }^{81}$ modern merchandising methods together with the behavior peculiar to shoppers and to thieves create an everpresent danger of reasonable but erroneous suspicion of theft. For example, when a clerk observes a woman who, after hovering about an uncovered dis. play, places an unwrapped article in her purse, he cannot be certain that she has not brought it to the store to match or compare with the items on the counter. $^{\$ 2}$ Furthermore, professional shoplifters often pave the way for claims of erroneous arrest by promptly transferring stolen goods to confederates. 83 And the deliberate feigning of shoplifting to induce store personnel to arrest unlawfully is a racket of serious proportions in some areas. ${ }^{31}$ Thus, the threat of unlawful arrest hangs over almost all attempts to apprehend shoplifters.

76. Interview, supra note 72 .

77. See, e.g., W. T. Grant Co., The Grant Sture Manual 3 (June 25, 1951); Supermarket News, August 11, 1952, p. 19, col. 4.

78. Interview, supra note 72.

79. Interview with department store manager, Toledo, Ohio, Lcc. 23,1452 (name withheld by request); Interview, supra note 72 .

S0. E.g., Schramko v. Boston Store of Chicago, 243 Ill. App. 251 (1927); Jeffercun Dry Goods Co. v. Stoess, 304 Ky. 73, 199 S.W.2d 994 (1947); Titus v. Montgomery Ward \& Co., 232 Mo. App. 987, 123 S.W.2d 574 (1938); Gold v. Armer, 140 App. Div. 73, 124 N.Y.Supp. 1069 (3d Dep't 1910). Contra: Coverstone v. Davies, 33' Cal.21 325, 239 P.2.1 876 (1952) (peace officer may arrest when he has reasonable ground to believe misdemeanor committed in presence); Hill v. Day, 168 Kan. 604, 215 P.2d 219 (1950) (same). See also Note, 25 So. CaLIF. L. Rev. 449 (1952).

Probable cause will, however, relieve defendant of liability for punitive damages. E.g., Titus v. Montgomery Ward \& Co., suspra.

81. See, e.g., Inbau, Minadul for Store Protrction 2-3 (1951) (prepared for and published by the Retail Special Services Ass'n, Inc., Chicago, Ill.).

82. "Honest customers often bring unwrapped merchandise into your store for exchange, refund, matching purposes and other reasons." RerurL Jifncunstrs Ass't: of Houston, Inc., op. cit. supra note 17. See, e.g., Winn \& Lovett Grocery Co. v. Archer, 126 Fla. 308, 171 So. 214 (1936) ; McCrory Stores Corp. v. Satchell, 148 Md. 279, 129 Atl. 348 (1925).

83. See PoLLAK, op. cit. supra note 2 , at 36.

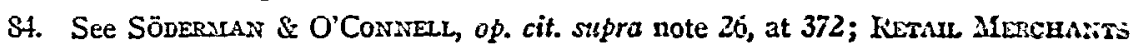
Ass's of Houston, Inc., op. cit. supro note 17. 


\section{Tort Consequences of Unlawful Arrest}

Merchants and peace officers must heed the restrictions of arrest law since any misstep gives rise to the popular tort action of false imprisonment. 85 Absent justification in law, any restraint against a person's will, either by force or fear, constitutes false imprisonment. ${ }^{86}$ An unlawful arrest is one form of the tort, ${ }^{87}$ and the victim may recover damages for loss of time, physical discomfort and injury, mental suffering due to humiliation, and injury to reputation..$^{88}$ The financially responsible mercantile establishments are sued most frequently, via respondeat superior for actions of store personnel, ${ }^{80}$ although suits against peace officers are not unknown..$^{00}$ And plaintiffs' judgments for several thousands of dollars are fairly common.11 Moreover, the

85. "Business men, because of painful experience gained through civil suits, are extremely wary of making arrests or initiating prosecutions [of shoplifters]. . ." Communication to the Yale Law Journal from J. D. Holstrom, Berkeley, Calif., Chicf of Police Dep't, dated December 3, 1952, in the Yale Law Library. See also Cracking Dotem on Shoplifters, supra note 5, at 61; Communication to the YALE LAw JOURNAL from F. L. Doyle, Albuquerque, N.M., Ass't Chief of Police Dep't, dated December 17, 1952, in the Yale Law Library.

On the other hand, peace officers frequently appear willing to ignore the law of arrest in their efforts to apprehend shoplifters. The officials of the Interstate Commission on Crime in 1939 estimated that over 75 percent of all arrests by peace officers are unlawful. Warner, Investigating the Law of Arrest, 26 A.B.A.J. 151 (1940). The Chicf of Police for a large eastern city, in answer to a questionnaire distributed by the YALE LAW JouRNAI, commented: "[A]n officer cannot arrest on a misdemeanor unless it is committed in his presence. However, the impracticalness of strict adherence to this policy should be obvious. ..."

86. E.g., Crews-Beggs Dry Goods Co. v. Bayle, 97 Colo. 568, 51 P.2d 1026 (1935); Miller v. Ashcraft, $98 \mathrm{Ky} .314,32$ S.W. 1085 (1895). See also Prosser, Torts \& 12 (1941). It is essential that the restraint be against the subject's "will." $E . / /$, Meineclce v. Skaggs, 123 Mont. 308, 213 P.2d 237 (1949); Fenn v. Kroger Grocery \& Baking Co., 209 S.W. 885 (Mo. 1919) ; James v. MacDougall \& Southwick Co., 134 Wash. 314, 235 Pac. 812 (1925). But cf. Great Atlantic \& Pacific Tea Co. v. Billups, 253 Ky. 126, 69 S.W.2d 5 (1934). It is not necessary, however, that plaintiff prove he attempted to escape. See, e.g., Titus v. Montgomery Ward \& Co., 232 Mo. App. 987, 123 S.W.2d 574 (1938).

False imprisonment is a misdemeanor in some states. E.g., Colo. Stat. ANN. c. 48, $\S 75$ (1936); N.J. StaT. ANN. \$2:103-1 (1939).

87. Grago v. Vassello, 173 Misc. 736, 19 N.Y.S.2d 34 (Sup. Ct. 1940). See ProssEr, TORTS $\S 12$ (1941).

88. E.g., S. H. Kress \& Co. v. Powell, 132 Fla. 471, 180 So. 757 (1938) ; W. T. Grant Co. v. Owens, 149 Va. 906, 141 S.E. 860 (1928).

89. E.g., Winn \& Lovett Grocery Co. v. Archer, 126 Fla. 308, 171 So. 214 (1936); Long v. Eagle 5, 10 and 25 Cent Store Co., 214 N.C. 146, 198 S.E. 573 (1938). Sec Comment, 47 N.U.L. REv. 82, 92-8 (1952).

90. "Seldom have I talked to five or six police officers without finding that one of them had at some time in his career been sued for false arrest." Warner, Investigating the Law of Arrest, 26 A.B.A.J. 151, 155 (1940). However, peace officers are often judgmentproof. Hopisins, Our Lawless Police 90 (1931). See also Hall, Police and Lazu in a Democratic Society, 28 IND. L.J. 133, 153-4 (1953).

91. E.g., Montgomery Ward \& Co. v. Medline, 104 F.2d 485 (4th Cir. 1939) (\$3,000); Jefferson Dry Goods Co. v. Stoess, 304 Ky. 73, 199 S.W.2d 994 (1947) $(\$ 3,048.40)$; J. J. Newberry Co. v. Judd, 259 Ky. 309, 82 S.W.2d 359 (1935) (\$1,750). 
frequency of high out-of-court settlements encourages the pressing of such claims. ${ }^{22}$ Although some large and prosperous mercantile concerns may insure against tort liability, ${ }^{33}$ most merchants apparently cannot afford the cost of such insurance. ${ }^{94}$

Cases in which an innocent person is mistakenly arrested for pilfering spawn the majority of false imprisonment actions against merchants. ${ }^{03}$ But guilty persons may also sue. A plea of guilty to, or conviction of, a misdemeanor does not bar the arrestee's false imprisonment suit grounded on unlawful arrest. $^{96}$ Unless he is demanding punitive damages, the plaintiff's guilt is apparently not admitted even to mitigate damages. ${ }^{97}$ The anomalous result: a guilty shoplifter may recover for mental anguish and loss of reputation occasioned by his arrest for shoplifting.

\section{Patterns of Self-Help}

The ever-present threat of tort liability for unlawful arrest has caused merchants to shun arrest in their struggle against shoplifting. ${ }^{83}$ Instead, merchants resign themselves to techniques of self-help. Store owners may place all small items in glass cases, post signs announcing that the establishment employs store detectives, instruct clerks to make their presence constantly felt by customers, strategically locate mirrors, and institute check-out systems of

92. Communication to the YALE LAW JouRNaL from counsel for a nation-wide chain of variety stores, dated November 24, 1952. (Name withheld by request.) See SurnersLand, The Professional Thief 49 n.7 (1937).

93. Communication to the YALE Law Jouraal from Richard A. Winsluw, Ass't Counsel, Liberty Mutual Insurance Co. (Boston, Mass.), dated March 13, 1953, in the Yale Law Library.

94. Interviews with store managers in New Haven, Conn., New York, N.Y., and Toledo, Ohio. (Names withheld by request.) See Communication to the Yale Law Journal from W. C. Leavitt, Mgr., Burglary \& Glass, Saint Paul-Mercury Indemnity Co. (St. Paul, Mrinn.), dated MIarch 25, 1953, in the Yale Law Library.

95. Interviews, supra note 94 . In few cases do the facts suggest that the plaintiff was guilty. See cases cited in first paragraph of note 97 infra.

96. E.g., Collins v. Owens, 77 Cal. App.2d 713, 176 P.2d 372 (1947) ; MrcCullough v. Greenfield, 133 Mich. 463, 95 N.W. 532 (1903); Crosswhite v. Barnes, 139 Va. 471, 124 S.E. 242 (1924). Contra: Erie R.R. v. Reigherd, 166 Fed. 247 (6th Cir. 1909).

97. E.g., Fitscher v. Rollman \& Sons Co., 31 Ohio App. 310, 167 N.E 469 (1929); S. H. Kress \& Co. v. Rust, 97 S.W.2d 997 (Tex. Civ. App. 1936), aff'd, 132 Tes: S9, 120 S.W.2d 425 (1938).

On the other hand, evidence of plaintiff's acquittal in the criminal action is not admissible at the trial of his false imprisonment claim. Pilos v. First National Stores, 319 Miass. 475, 66 N.E.2d 576 (1946). Costra: Allen v. William J. Burns International Detective Agency, 121 Ore. 492, 256 Pac. 197 (1927).

A plea of guilty by, or conviction of, plaintiff would probably rebut a claim for punitive damages. See Collins v. Owens, 77 Cal. App.2d 713, 717, 176 P.2d 372, 375 (1947); Crosswhite v. Barnes, 139 Va. 471, 4\$4-5, 124 S.E. 242, 246 (1924). See also Nute, 27 Notre Dasie Law. 252, 257 (1952).

98. See first paragraph of note 85 supra. 
parcel inspection..$^{99}$ Most important, when these devices fail to deter the shoplifter, merchants will deal with suspects without resort to police assistance. ${ }^{100}$ The retailer can, of course, seek to settle cases on an amicable, voluntary basis without risk of tort liability. ${ }^{101}$ Moreover, a merchant who has lost possession of his property as the result of a wrongful taking may demand its return; if return is refused and he acts promptly, the property owner may recapture his goods by reasonable force. ${ }^{102}$ However, he may never use force to coerce pay ment, ${ }^{103}$ and he will be liable for assault and battery or false imprisonment if the suspected pilferer has in fact taken nothing, ${ }^{104}$ or is in rightful possession of the goods. ${ }^{105}$ Thus the merchant's forcible attempt at recaption, like his arrest of a suspect, is undertaken at peril. ${ }^{106}$ Furthermore, merchants often go beyond the common-law recaption doctrine by detaining and searching the suspect against his will. ${ }^{107}$ While the absence of an intent to prosecute the suspect avoids the "arrest" label, ${ }^{108}$ the tort consequences are the same. ${ }^{100}$

99. See, e.g., U.S. Dep't of Conmeree, Small Business Aid No. 469, Gunkding Against Theft of Retail Merchandise (October, 1948) ; The Gentle Art of Stroplifting and How to Remove TeMptation, op. cit. supra note 53; Cracking Dozem on Shoplifters, supra note 5, at 61 . Detention of a customer at a check-out point for parcel inspection may, however, result in a false imprisonment. Great Atlantic \& Pacific Tea Co. v. Smith, $281 \mathrm{Ky} .583,136$ S.W.2d 759 (1940).

100. See, e.g., Peterson, Crime Does Pay, The Atlantic, February, 1953, pp. 38, 39.

101. There can be no false imprisonment where the suspect co-operates voluntarily. See note 86 supra.

102. Restatenent, Torts $\$ \$ 100-6$ (1934). E.g., Winter v. Atkinson, 92 Ill. App. 162 (1900); Curlee v. Scales, 200 N.C. 612, 158 S.E. 89 (1931). See Branston, The Forcible Recaption of Chattels, 28 L.Q. Rev. 262 (1912) passim.

There also exists at common law a right, in some situations, to defend one's personal property by force to prevent a threatened wrongful taking. E.g., Gyre v. Culver, 47 Barb. Ch. 592 (N.Y. 1867). Shoplifting rarely presents such a case, however. See Comment, 46 ILL. L. REv. 887, 889-92 (1952).

103. Mannaugh v. J. C. Penney Co., 61 S.D. 550, 250 N.W. 38 (1933). Requiring a shoplifter to pay a lump sum in restitution for supposed previous thefts may result in conviction for extortion. People v. Fichtner, 118 N.Y.S.2d 392 (2d Dep't 1952).

104. E.g., McCrory Stores Corp. v. Satchell, 148 Md. 279, 129 Atl. 348 (1925); Scott-Burr Stores Corp. v. Edgar, 181 Miss. 486, 177 So. 766 (1938).

105. Johnson v. Perry, 54 Vt. 459 (1882). See S. H. Kress \& Co. v. Musgrove, 153 Va. 348, 149 S.E. 453 (1929).

106. See note 80 supra and accompanying text.

107. E.g., Hassenauer v. F. W. Woolworth \& Co., 314 Ill. App. 569, 41 N.E.2d 979 (1942) ; Coolahan v. Marshall Field \& Co., 159 Ill. App. 466 (1911) ; Hurst v. Montgomery Ward \& Co., 145 S.W.2d 992 (Mo. App. 1940); Perkins Bros. v. Anderson, 155 S.W. 556 (Tex. Civ. App. 1913). See also Anon., suipra note 21, at 45-6.

108. See note 46 sipra.

109. See note 86 supra and accompanying text. Such detention would be no moro justified if made by a peace officer. Although no cases denying the right were found, it seems clear under most statutes that a peace officer could not justify even brief detention of a suspected shoplifter against his or her will for questioning. See MACHEN, THE LAW of ARRest $\$ \S 3,51$ (1950); Waite, The Law of Arrest, 24 Texus L. Rkv. 279, 296-8 
Yet suspected shoplifters often fail to sue for false imprisonment if they have been spared a trip to the police station. ${ }^{110}$ And in some cases the store may be able to obtain from the detained suspect a voluntary release from tort liability. ${ }^{111}$

Mindful of the retailer's plight, courts in five states hold that a reasonable detention for investigation, if based upon probable cause, is not actionable.112 Even in these states the rule is only a halfway solution to the shoplifting dilemma. Practical obstacles may prevent store employees from personally apprehending a shopper for questioning. The suspect may struggle violently, or run from the store; or, once apprehended, he may refuse to answer questions. In these situations, the merchant may wish to solicit police aid-but to do so would throw him back into the dangerous area of standard arrest doctrine. ${ }^{113}$ Where detention and questioning are possible, the merchant may, of course, persuade the thief to confess his guilt and return the stolen item, ending the episode without need or desire to seek legal sanctions. But if, as a result of the interview, the retailer considers his suspicions confirmed, the "presence" and "at peril" doctrines ${ }^{114}$ may then frustrate any attempt to translate the detention into a bona fide arrest for purposes of legal action against the supposed offender.

In recent years, American merchants have discovered that self-help, divorced from assistance by law enforcement agencies and without prosecution of of-

(1946). Massachusetts, New Hampshire, and Rhode Island, however, spasifically Trant peace officers power, under certain circumstances, to detain persons for questioning. MAsS. ANN. Laws c. 41, \$98 (1952) ; N.H. Laws 1941, c. 163, \$2; R.I. Pub. Laws 1941, c. 982, $\$ 68$, cl. 1. See also text of proposed Uniforar ARnest ACr, reproduced in Wamer, The Uniform Arrest Act, 28 VA. L. Kev. 315,343 (1942).

110. Interviews with, and communications from, retail store managers and merchants' legal counsel in New York, N.Y., and Chicago, Ill. (Names withheld by request.)

111. Protection manuals of department and chain stores usually contain instructions for obtaining releases. (Names of stores withheld by request.) Also, written confessions are often demanded of shoplifting suspects. See Anon., supra note 21, at 26 . For an extreme effort to obtain a confession, see Adams v. F. W. Woolworth Co., 144 Mise. 27, 257 N.Y.Supp. 776 (Sup. Ct. 1932).

112. Montgomery Ward \& Co. v. Freeman, 199 F.2d 720 (4th Cir. 1952) (Virginia); Kroger Grocery \& Baking Co. v. Waller, 201 Ark. 1063, 189 S.W.2d 361 (1945); Bettolo v. Safeway Stores, 11 Cal. App.2d 430, 54 P.2d 24 (1936); Teel v. May Department Stores Co., 348 11o. 696, 155 S.W.2d 74 (1941); Cohen v. Lit Bros., 166 Pa. Suner. 205, 70 A.2d 419 (1950). Contra: Jefferson Dry Goods Co. v. Staess, 304 Ky. 73, 199 S.IW.21 994 (1947); Martin v. Castner-Knott Dry Goods Co., 27 Tenn. App. 421, 181 S.WY.21 638 (1944).

As to the reasonableness of delay before delivering an arrested shoplifting suspet to a magistrate or peace officer, see John Lewis \& Co., Ltd. v. Sims, [1952] A.C. G70 (arrested shoplifting suspect detained in shop until chief store detective and managing directer could hear evidence).

113. The decisions cited in note 112 stspa apply exclusively to merebant self-licls; they do not alter the statutory rules of arrest already discussed.

114. See pages $796-7$ supra. 
fenders, cannot cope with the shoplifting problem. ${ }^{115}$ Retailers agree that the crime is on the uptrend:116 some merchants have reported a 25 to 30 percent increase in pilfering in 1952 over the previous year. ${ }^{117}$ Thus retailers currently announce a desire to co-operate with law enforcement agencies in effecting the arrest and prosecution of store thieves. ${ }^{118}$ Only workable rules of arrest can implement this new policy.

\section{A Proposed Shoplifting Arrest Statu'te}

A revision of law should broaden the merchant's and peace officer's power to detain and arrest without subjecting the innocent shopper to the burden of arbitrary restraint and questioning. ${ }^{110}$ To further this policy, the following is proposed as a model arrest statute to govern the detention and arrest of persons suspected of store larceny:

1. A peace officer, or a merchant, or a merchant's employee, may use reasonable force to detain for questioning for a reasonable length of time on the merchant's premises any person whom he has reasonable ground to believe has committed larceny of goods displayed for sale by the merchant. Such detention shall not constitute an arrest.

2. A peace officer may arrest without warrant any person whom he has reasonable ground to believe has committed larceny of goods displayed for sale. A charge made to a peace officer by a merchant or a merchant's employee shall constitute a reasonable ground for such arrest. No merchant or merchant's employee shall be criminally or civilly liable for false arrest or false imprisonment of any person arrested under this paragraph where said merchant or merchant's employee had a reasonable ground for charging said person with commission of larceny of goods displayed for sale.

The first paragraph of the suggested enactment, based upon the current rule in a few states, ${ }^{120}$ permits reasonable detention and questioning without resort

115. See Cracking Dozen on Shoplifters, supra note 5, passint. See also note 116 infra.

116. See Address of Edward Wetton, supra note 2; Address of S. W. Landon, Shortage Controller, The Hecht Co. (Washington, D.C.), at Convention of Controllers' Conga, of the Nat. Retail Dry Goods Ass'n, May 28, 1952; Communication to the YALE LAW Journal from Raymond J. Burns, Pres. of Wm. J. Burns Internat'l Detective Agency, Inc., dated December 22, 1952, in the Yale Law Library.

117. See Cracking Doun on Shoplifters, supra note 5, at 58.

118. See id. at 61 ; Women's Wear Daily, January 18, 1952, p. 47, col. 3; Stupermarket News, June 9, 1952, p. 8, col. 5; Supermarket News, July 28, 1952, p. 8, col. 1.

119. A statute allowing arbitrary arrest without warrant would be unconstitutional. See, e.g., Pinkerton v. Verberg, 78 Mich. 573 (1889). Whether a statutory extension of arrest powers beyond the common-law rule is constitutional depends on its "reasonableness." See, e.g., Snyder v. United States, 285 Fed. 1 (4th Cir. 1922); Tarantina v. Lotisville Ry. Co., 98 N.E. 999 (Ill. 1912). See also Warner, The Uniform Arrest Act, 28 VA. L. REv. 315, 323 (1942).

120. See note 112 supra and accompanying text. See also N.H. Laws 1941, c. 163, $\S 2$; R.I. Pub. Laws 1941, c. 982, §68, cl. 1. 
to arrest procedures. Such legislation would conform the law to existing institutional practices, ${ }^{121}$ allowing a merchant who did not witness the shopper's conduct to undertake an investigation where he has reasonable ground to believe the person guilty of shoplifting. The merchant may apprehend the suspect without loss of vital time in the search for a peace officer, or jeopardizing customer goodwill by the presence of police in the store. If the detained suspect demonstrates his innocence, he will have been spared the stigma of arrest. However, if the suspect proves recalcitrant, the merchant can summon a peace officer who did not view the offence; because of his position of authority, the officer may have greater success in questioning the subject. So long as the "reasonableness" requirements of the paragraph are met, neither the merchant nor the peace officer will be liable in tort for false imprisonment or assault and battery. The merchant's desire to maintain good public relations will probably serve as a practical restraint upon arbitrary detention..$^{122}$

The second paragraph of the proposed legislation, modeled in part on the arrest statutes of Rhode Island and Wisconsin, aims a more permissive rule of arrest specifically at the store thief. ${ }^{123}$ A merchant might reasonably determine, on the basis of his or an employee's observation, or upon observation supplemented by questioning privileged under paragraph one, to instigate the arrest of a shoplifting suspect who would otherwise escape unchallenged. The merchant may then summon a peace officer who, under paragraph two of the proposed statute, could make a lawful arrest without warrant on the basis of the merchant's communication. ${ }^{124}$ The suggested legislation would remove the restrictive "at peril" aspects of such an arrest: even if the suspect eventually proved guiltless, the peace officer would not be liable for false imprisonment, nor would the merchant or an employee if he had reasonable ground for requesting the arrest. ${ }^{125}$ Under this statute, merchants and law enforcement agencies may co-operate in a sustained effort to combat shoplifting and related criminal activity.

121. See note 107 supra and accompanying text.

122. See text at notes 78 and $S 1$ supra.

123. See R.I. Pub. Laws 1941, c. 982, $\$ 6 \&$, cl. 5 ; WIs. STAr. $\$ 354.03$ (1951). Metropolitan police departments have advocated such legislation. Sce Comment, 39 CnLrr. L. REv. 96, 104 (1951) ; Communication to the Yale Law Jourma from Harold Andersen, Chief of Detectives, Kansas City, Mo., Police Dep't, dated December 16, 1952, in the Yale Law Library.

For a similar recommendations, consult Potts, The Low of Arrest, 1 Baycos L Rer. 397, 409 (1949) ; Stone, Arrest Without Warrant by a Peace Officer is Neac Yorl, 21 N.Y.U.L.Q. REv. 61, 87 (1946).

124. Cases have long held that the accusatory statements of a credible person provide an arrester with "reasonable ground" to arrest. E.g., Smith v. Tate, 143 Tenn. 268,227 S.W. 1026 (1920). See Perkins, The Law of Arrest, 25 Iowa L. Rev. 201, 239 (1910).

See Cal. Penal Code $\$ \$ 36$ (Deering, 1941), Dowdell v. Owl Drug Co., 121 Cal. App. 316, \& P.2d 890 (1932). See also Haggard v. First Nat. Bank of Mandan, 72 N.D. 437, 8 N.W.2d 5 (1943).

125. The cases are not in harmony as to whether the authority possessed by peace officers in some situations to arrest without warrant on probable cause shiclds from lia- 


\section{APPENDIX}

Official Disposition of Shoplifting Cases in Sixty-Five Cities During 1951

\section{Cities}

1. Akron, Ohio

2. Albuquerque, N.M.

3. Baltimore, Md.

4. Berkeley, Calif.

5. Bloomington, Ind.

6. Boston, Mass.*

7. Bridgeport, Conn.

8. Canton, Ohio

9. Cedar Rapids, Iowa

10. Chattanooga, Tenn.

11. Cleveland, Ohio

12. Columbia, Mo.

13. Columbus, Ohio

14. Dallas, Texas

15. Dayton, Ohio

16. Denver, Colo.*

17. Detroit, Mich.

18. Durham, N.C.

19. Elmira, N.Y.

20. Everett, Wash.

21. Fort Wayne, Ind.

22. Glendale, Calif.

23. Grand Forks, N.D.

24. Hartford, Conn.

25. Joplin, Mo.

26. Kansas City, Mo.

27. Lima, Ohio

28. Little Rock, Ark.*

29. Manchester, N.H.

30. Miami, Fla.
Cases: Knozen by Arrest Prosecuted Convicted Acquilted

\begin{tabular}{|c|c|c|c|c|}
\hline 100 & 78 & 一 & - & - \\
\hline 18 & 18 & 18 & 18 & 0 \\
\hline 400 & - & - & 一 & - \\
\hline 242 & 65 & 14 & 14 & 0 \\
\hline 1 & - & 0 & 0 & 0 \\
\hline 62 & 24 & 24 & 24 & 0 \\
\hline 11 & 11 & 11 & 11 & 0 \\
\hline 48 & 43 & 43 & 43 & 0 \\
\hline 20 & 10 & 5 & 5 & 0 \\
\hline 367 & 267 & 267 & 259 & 2 \\
\hline - & 1 & 1 & - & 一 \\
\hline - & 186 & - & - & - \\
\hline 336 & - & - & - & - \\
\hline 193 & 135 & - & - & - \\
\hline 428 & 428 & 428 & - & - \\
\hline 34 & 29 & 29 & 27 & 2 \\
\hline 7 & - & - & 一 & 一 \\
\hline 29 & 21 & 21 & 21 & 0 \\
\hline 6 & 6 & 3 & - & - \\
\hline 30 & 27 & - & 一 & - \\
\hline 14 & 12 & 10 & 10 & 0 \\
\hline 111 & 111 & 111 & - & - \\
\hline "Few" & "Several" & "Not many" & - & - \\
\hline 165 & 58 & - & - & - \\
\hline - & 13 & 12 & 1 & - \\
\hline 42 & 31 & 31 & 31 & 0 \\
\hline 307 & 246 & 98 & - & - \\
\hline
\end{tabular}

bility for false imprisonment a private person whose oral charges alone provided the probable cause. Many cases hold that the private person's liability is to be determined as though he himself made the arrest. Compare Harris v. Terminal R. Ass'n, 203 Mo. App. 324, 218 S.W. 686 (1920) ; Grinnell v. Weston, 95 App. Div. 454, 88 N.Y.Supp. 781 (1st Dep't 1904), with Van v. Pacific Coast Co., 120 Fed. 699 (C.C. Wash. 1903); Haggard v. First Nat. Bank, 72 N.D. 434, 8 N.W.2d 5 (1943). The final sentence in $\llbracket 2$ of the proposed statute renders a merchant or his employee immune from liability where he had reasonable ground to request an arrest.

$\dagger$ These statistics were compiled from replies to a questionnaire distributed by the YALE LAw Journal to 125 cities of 25,000 population or over. Dismissals, probations, references to juvenile guidance personnel, and other special dispositions are not listed. Copies of the questionnaire and the 65 replies are on file in the Yale Law Library.

¥"Cleared by arrest" means police considered case solved and thus closed on arrest.

*Information unavailable. Dash (-) indicates information not included in reply to questionnaire. 


\section{Cities}

31. Milwaukee, Wis.

32. Minneapolis, Minn.

33. Moline, IIl.

34. Morgantown, W. Va.

35. Muskegon, Mich.*

36. Newark, N.J.

37. New Haven, Conn.

38. New Orleans, La.

39. New York, N.Y.*

40. Oak Ridge, Tenn.*

41. Oalland, Calif.

42. Omaha, Neb.

43. Peoria, IIl.

44. Pittsburgh, $\mathrm{Pa}$.

45. Portland, Me.

46. Racine, Wis.

47. Roanoke, Va.

48. Rockford, Ill.

49. Saginaw, Mich.

50. St. Paul, Minn.

51. Salina, Kans.

53. San Diego, Calif.

54. San Francisco, Calif.

55. Sheboygan, Wis.

56. South Bend, Ind.

58. Tacoma, Wash.

59. Toledo, Ohio

60. Topeka, Kans.

61. Trenton, N.J.

62. Waterloo, Iowa*

63. Wichita, Kans.

64. Worcester, Miass.

65. Yakima, Wash.
52. San Antonio, Texas

57. Springfield, Mass.

\section{Cleared}

Cases: Knoant by Arrestł Proseculed Conicied .Icquiltid

$\begin{array}{rrrrrr}17 & 9 & 9 & - & - \\ -17 & 90 & 90 & 90 & 0 \\ 25 & 11 & 11 & 11 & 0 \\ 102 & 14 & - & - & - \\ 103 & 8 S & 8 s & 98 \% & - \\ 125 & 125 & 125 & - & -\end{array}$

\begin{tabular}{|c|c|c|c|c|}
\hline 451 & 301 & - & - & - \\
\hline 169 & 166 & 166 & 166 & 0 \\
\hline 30 & 27 & 21 & 19 & - \\
\hline- & 186 & 185 & 186 & 0 \\
\hline - & - & "4 or 5" & - & - \\
\hline 25 & 16 & 16 & 6 & 1 \\
\hline 23 & 16 & 16 & 16 & 0 \\
\hline 161 & - & - & - & - \\
\hline 52 & 50 & 8 & 7 & - \\
\hline 175 & 一 & 130 & 130 & 0 \\
\hline - & - & "All" & "Most" & - \\
\hline (1952) & 327 & - & - & - \\
\hline 146 & 65 & 56 & 50 & - \\
\hline 1150 & 323 & 323 & 323 & 0 \\
\hline 11 & 6 & 6 & 6 & 0 \\
\hline 33 & 18 & 18 & 18 & 0 \\
\hline 72 & 65 & 65 & 65 & 0 \\
\hline 42 & 35 & - & - & - \\
\hline 264 & 66 & - & - & - \\
\hline 30 & 12 & 12 & - & - \\
\hline 42 & 40 & 40 & 38 & 2 \\
\hline 166 & 139 & 43 & 36 & - \\
\hline 2 & 2 & 2 & 0 & 0 \\
\hline- & 90 & 90 & 90 & 0 \\
\hline
\end{tabular}

$\frac{+}{+}$ "Cleared by arrest" means police considered case solved and thus closed on arrest.

*Information unavailable. Dash $(-)$ indicates information not included in reply to questionnaire. 